\title{
The Analysis of the Model of Damping Mechanism for Shipborne Labyrinth Compressor Pis- ton Components
}

Peng Ba ${ }^{1}$, Yuwei Zhang ${ }^{1}$, Shi Jia ${ }^{2}$

${ }^{1}$ School of Mechanical Engineering, Shenyang Ligong University, Liaoning Shenyang 110159, China. Email:bpbpppp@163.com, E-mail: yw9009z@163.com

${ }^{2}$ School of Mechanical Engineering \& Automation, Northeastern University, Shenyang 110819, China. Email: jiashineu@163.com

Piston parts of a shipborne labyrinth compressor are mainly composed of a piston and a coated piston rod. In recent years, many studies have shown that the vibration response of coating structure is significantly reduced. Because of the non-contact of the piston, the cylinder case and guide support entirely depends on the piston rod. The lateral jitter can be regarded as the vibration of cantilever beam. However there is no effective method to separate the contribution of hard-coating damping from the damping of composite system. In this paper, based on separating the damping contribution of hard coating, the method of creating the damping mechanism model of piston rod is studied. Firstly, the piston rod before and after coating are tested and the characteristic parameters of vibration, such as natural frequency, damping ratio, vibration response are acquired. Moreover, according to the analysis of the storage and dissipation energy in the uncoated and coated rod, the damping contribution of hard coating has been confirmed. Finally, the Oberst beam theory is adopted to create the damping mechanism model of piston rod which includes both material damping and viscous damping. The correctness of analytical model is also verified by the experiment results.

Keywords: Hard Coating, Piston Rod, Damping Mechanism, Analysis Model, Basement Exciting

\section{Acknowledgement}

Supported by Engineering Research Center Construction Project in Shenyang(NO.F13250800) and National University City Seed Found Project (NO.2003002).

\section{References}

[1] Reciprocating Compressors for Petroleum, Chemical, and Gas Industry Services API Standard 618, Fifth Edition, (June 2008). pp: 27-29. American Petroleum Institute.

[2] Lubrication, Shaft-Sealing, and Control-Oil Systems and Auxiliaries for Petroleum, Chemical and Gas Industry Services, Fourth Edition, April 2008. American Petroleum Institute.

[3] SHIPTON, M., PATSIAS, S. (2003). Hard damping coatings: internal friction as the damping mechanism. In: Proceedings of 8th National Turbine Engine High Cycle Fatigue Conference.

[4] BlackWell, C., PAlazotTo, A., GeORGE, T. J., et al. (2007). The evaluation of the damping characteristics of a hard coating on titanium [J]. In: Shock and Vibration, Vol. 14, No. 1, pp. 37-51.

[5] IVANCIC, F., PALAZOTTO, A. (2005). Experimental considerations for determining the damping coefficients of hard coaings [J]. In: Journal of Aerospace Engineering, Vol. 18, pp. 8-17

[6] GUANGYU, D., ZHEN, TAN., DECHUN, B., et al. (2012). Preparation and damping properties of NiCrAlY coating by arc ion plating[J]. In: Journal of Northeastern University (Natural Science), Vol.33, No.5, pp: 727-730.

[7] GUANGYU, D., DECHUN, B., ZHEN, TAN. et al. (2013). Vibration damping performance of ZrTiN coating deposited by arc ion plating on TC4 Titanium alloy [J]. In: Surface and Coatings Technology, Vol. 229, pp: 172175.

[8] EMERSON, E. N., Seung M. Y. (2011). Tribological study of high bearing blended polymer-based coatings for air-conditioning and refrigeration compressors [J]. In: Surface and Coatings Technology, Vol. 205, pp: 2994-3005.

[9] NICHOLAOS, G. D., ANDREAS A. P. (2008). Tribological performance of PTFE-based coatings for airconditioning compressors [J]. In: Surface and Coatings Technology, Vol. 203, pp: 307-316.

[10] FEUERSTEIN, A., KLEYMAN, A. (2009). Ti-N multilayer systems for compressor airfoil sand erosion protection [J]. In: Surface and Coatings Technology, Vol. 204, pp: 1092-1096.

[11] ANDI, M. L., TUAN, L. D., GIULIANO, G., DAVID R. C. (2007). High-temperature vibration damping of thermal barrier coating materials. In: Surface and Coatings Technology, Vol. 202, pp: 693-697. 
[12] XUEQIN, W., YANLING, P., (2013). Effect of microstructure at interface between coating and substrate on damping capacity of coating systems [J]. In: Applied Surface Science, Vol. 282, pp: 60-66.

[13] PATSIAS, S., SAXTON, C., SHIPTON, M. (2004). Hard damping coatings: an experimental procedure for extraction of damping characteristics and modulus of elasticity [J]. In: Materials Science and Engineering: A, Vol. 370, pp: 412-416.

[14] TORVIK, P. J. (2009). A slip damping model for plasma sprayed ceramics [J]. Journal of Applied Mechanics, Vol. 76, No. 6, pp: 10-18.

[15] ABU, R. K., PALAZOTTO, A. N. (2010). Micromechanical theoretical and computational modeling of energy dissipation due to nonlinear vibration of hard ceramic coatings with microstructural recursive faults [J]. In: International Journal of Solids and Structures, Vol. 47, No. 16, pp: 2131-2142

[16] TASSININ, N., PATSIAS, S., LAMBRINOU, K. (2006). Ceramic coatings: a phenomenological modeling for damping behavior related to microstructural features [J]. In: Materials Science and Engineering: A, Vol. 442, No. 1, pp: 509-513.

[17] KUŚMIERCZAK, S., SVOBODOVÁ, J. (2012). Microscopic evaluation of protective coating by coated sheets after corrosion load [J]. In: Manufacturing Technology, Vol. 12, No. 13, pp: 151-157.

[18] SRIKANTHA, P. A., WOODHOUS, J. (2007). Viscous damping identification in linear vibration [J]. In: Journal of Sound and Vibration, Vol. 303, No.3, pp: 475-500.

[19] SOVIAROVÁ, A., PALČEK, P., TROJANOVÁ, Z. (2014). Monitoring of precipitation process in AZ31 and AZ91 magnesium alloys by internal damping measuremen [J]. In:Manufacturing Technology, Vol. 14, No. 3, pp: 447-451

[20] TORVIK, P J. (2011). On estimating system damping from frequency response bandwidths [J]. In: Journal of Sound and Vibration, Vol. 330, No. 25, pp: 6088-6097.

[21] MAGALHAES, F., CUNHA, A., CAETANO, E., et al. (2010). Damping estimation using free decays and ambient vibration tests [J]. Mechanical Systems and Signal Processing, Vol. 24, No. 5, pp: 1274-1290.

[22] LUKOVICS, P. (2013). Evaluation of vibration on technological devices. In: Manufacturing Technology, Vol.14, No.3, pp. 345-349.

[23] BANGCHUN, W. (2009). Theory of mechanical vibration and its application [M]. Higher Education Press, Beijing.

[24] DIHUA, L. (1990). Viscoelastic damping vibration noise reduction technology [M]. Aerospace Press, Beijing. 